DOI: https://doi.org/10.47405/mjssh.v6i8.943

\begin{tabular}{|c|c|}
\hline 4 & Malaysian Journal of Social Sciences and Humanities (MJSSH) \\
\hline $\begin{array}{l}\text { Malaysian Juoural of } \\
\text { Social ccciecces and }\end{array}$ & Volume 6, Issue 8, August 2021 \\
\hline (MJ-sSH) & e-ISSN : 2504-8562 \\
\hline & $\begin{array}{l}\text { Journal home page: } \\
\text { www.msocialsciences.com }\end{array}$ \\
\hline
\end{tabular}

\title{
Effects of Social Media Marketing Towards Probiotic Chicken Customers' Purchase Intention: Customer Engagement as a Mediator
}

\author{
Nadia Ambar Shofiya ${ }^{1}$, Ira Fachira ${ }^{1}$ \\ ${ }^{1}$ School of Business and Management, Institut Teknologi Bandung, Indonesia \\ Correspondence: Nadia Ambar Shofiya (ambrshf667@gmail.com)
}

\begin{abstract}
Social media has become an inseparable part of marketing, particularly for small and medium enterprises. However, there is a limited knowledge on how it helps small and medium enterprises in selling probiotic products. This study aims to explore how social media marketing influences the purchase intentions of probiotic chicken customers. This research uses a quantitative approach to collect data through an online survey from 215 participants. The results show that the factors of entertainment, trendiness, and e - word of mouth of social media marketing, alongside customer engagement, significantly affect customers' purchase intentions. Data analysis reveals that the factors of social media marketing have greater influence towards purchase intention when mediated by customer engagement, compared to their direct influence towards purchase intention. Therefore, improving the quality of the social media marketing factors enhances customer engagement. Hence, customer engagement also plays an important role in social media marketing by directly influencing the customers' purchase intentions.
\end{abstract}

Keywords: social media marketing, purchase intention, customer engagement

\section{Introduction}

In this digitization era, businesses gather to attract customers through the advantage that the online world provides. According to a survey done by Clutch in 2018, 64\% of small businesses have a website. 58\% that do not have a website say they are planning to (Deigado, 2018). Among the key reasons behind small businesses to not have a website, $21 \%$ of them state that social media already gives them sufficient output (Deigado, 2018). It is reasonable to substitute website with social media. By 2021 itself, there are over three billion users of social media worldwide, with Facebook as the biggest platform ( 2.74 billion users), followed by WhatsApp ( 2 billion users) and Instagram (1.22 billion users) (Chen, 2021). Along with the rise of social media usage, small and medium enterprises in Indonesia start to recognize its' ability to bring positive impact to their businesses. Indonesia's active users of social media had reached 170 million by 2021, and 61,8\% of its population are active in one or more social media applications (Stephanie, 2021). According to Sri Widowati, Country Director of Facebook Indonesia, there are over 7 million brands optimizing their marketing through Instagram that is integrated to Facebook (Setyowati, 2019). In 2020, a survey was done by Badan Pusat Statistik, showing that the majority of 17.063 enterprises in Indonesia, with a revenue of up to 300 million rupiah, use instant messaging and social media as their sales media. Hence, social media plays a big role in Indonesian brands' marketing. 
Brands from different industries are swarming the platforms to find new customers, including the probiotic chicken industry. The probiotic chicken industry is part of the broiler chicken industry, where chickens are fed with Lactobacillus bacteria and herbs as food support to grow fast without the use of antibiotics and hormones (Trifiana, 2019). Currently, probiotic chicken is rising in demand as $90 \%$ of Indonesian households are consuming healthier menus during the covid-19 pandemic (Kantar Worldpanel Indonesia, 2020). Moreover, nutritionists predict that probiotics will rise in trend in 2021 (Afrilian, 2020). Probiotic chicken brands in Indonesia are using social media as one of their primary marketing channels, but it cannot be determined whether social media creates a significant impact to their sales.

At the same time, issues of customer engagement appear to have received substantial consideration in research concerning social media. Dessart et al. (2015) had found evidence of online brand communities experiencing engagement among community groups and direct customer-brand relationships in the online realm. The subjects of their research reported elements of customer engagement helped in driving purchase. Thus, with the growing technology, brands need to think ways to make use of social media not only to obtain revenue but also to create a long-lasting engagement with their customers. Cummins et al. (2014) also mentioned that the extent of customer engagement in social media include possible increase in customer satisfaction, retention, loyalty, customer lifetime value, and profitability. Kaplan \& Haenlein (2010) mentioned how it is customary within social media for customers to be able to interact with brands. Through customer-brand engagement in social media, bonds can be easily formed to create value, and thus could lead to favourable results to the brand.

Nonetheless, the subject of social media along with customer engagement is still under-researched (Barger et al., 2016; Dessart et al., 2015; Husnain et al., 2017). Knowing the potential that social media offers, such as Instagram offering an engagement rate of $1.18 \%$ per post for food and beverage industry, and Facebook offering $0.10 \%$ respectively, they become an opportunity that are hard to miss by marketers (Chen, 2021). But it is also known that social media marketing does not generate equally profitable results for all industries. It has been revealed that social media is an effective platform for brands that include fashion, food, and technology, but is less effective to financial services (Guo, 2016). Therefore, there is a lot of potential that can be explored from social media as a marketing platform towards the purchase intention of a probiotic chicken business. This research also intends to analyse the role of customer engagement within the relationship between social media marketing and customers' purchase intention.

\section{Literature Review}

\section{Social Media Marketing}

Social media is a collection of applications that are based on the web that allow the creation and the exchange of user-generated content (Kaplan, 2015). User-generated content comes from users of social media who voluntarily give information, data or media in a useful or entertaining way (Krumm et al., 2008). The extent of social media has challenged businesses to understand how to best utilize the various social medias available on the internet to attract users to their brands and convert sales. Each social media application is unique in their nature. Hazlett (2010) mentioned that social media is used as a reference for many services on the internet that drove the users to participate in creating and exchanging content, joining into online communities (e.g., Tumblr, Reddit), social media sites (e.g., Instagram, Facebook), and media sharing sites (e.g., YouTube, Tik Tok). The components of social media marketing have been part of discussions in several subjects, such as consumer goods. Kim \& Ko (2012) characterized social media marketing activity entertainment, interaction, trendiness, customization, and word-of mouth (WOM) which were implemented to luxury products. It is also known that in the fast beverage industry, social media marketing activities are categorized into entertainment, interaction, trendiness, advertisement and customization (Jo, 2013). Sano (2009) also identified the components of social media advertising including interaction, trendiness, customization, and perceived risk which was applied on an insurance service. 


\section{Customer Engagement}

Customer engagement refers to the process of human psychology which shapes customers' loyalty towards a newly discovered brand, along with the mechanism that allows sustainability towards repeated purchase (Bowden, 2009). Customer engagement is one of the media component of a brand that a customer has encountered that leaves an impression that is favourable towards the brand (Cummings, 2007). It is also known that the use of social media by the masses support customer engagement (Pütter, 2017). Unlike more traditional marketing strategies in which customers were mere recipients of information, the newer mediums of marketing, including social media requires engagement in consideration as it plays a big role to let the consumer participate in, and influence the way of the interaction within the business. Vivek (2009) suggests in his research on the scale of customer engagement, that the dimensions of the theory of consumption values (Sheth et al., 1991) are used when observing the outcome of customer engagement; as the level of customer engagement is associated with the value received by the consumer. Vivek (2009) derived both intrinsic and extrinsic values of a business's customer engagement to be associated with higher customer goodwill, word of mouth (WOM), connections with the organization, and affective commitment.

\section{Purchase Intention}

Intention is used by brands to predict the sales of upcoming products or to predict the repeated purchase of an existing product (Diallo, 2012). Purchase intention occurs within the customer journey where the customer has had their readiness to purchase a product (Dodds et al., 1991). In another word, purchase intention becomes an imperative indicator to predict the likelihood for a customer to purchase a product. Many studies have identified factors that are affective towards purchase intention. In the online realm itself, more than 80 factors are identified as influential towards purchase intention (Chang et al., 2005; Rose et al., 2012; Thamizhvanan \& Xavier, 2013). Regarding social media, the extent of it shows that the applications may contribute in improving the consumer decision making process more than traditional methods (Bruhn et al., 2012). It is also known that customer engagement may serve in increasing purchase intention among customers (Husnain et al., 2017). The role of customer engagement as a mediator of the study could facilitate marketers in interacting with social media marketing to increase customer purchasing intention. Since it is not possible to explore all the factors that are affective towards customer purchase intention, this research is restricted to investigating the effect of social media marketing and customer engagement towards purchase intention.

\section{Hypothesis Development}

As a mean to provide communication with customers, now brands in the broiler chicken industry have shifted to social media. Social media is a perfect fit for providing two-way communication among brands and users. The interaction between users and brands in social media has helped create positive attitude towards the brands present. Furthermore, they may support stronger user commitment and affect the decision-making towards a purchase (Hutter et al., 2013). It has also been found that social media marketing influences purchase intention (Z. Wang et al., 2016). Therefore:

H1: There is a positive relationship between the social media marketing factors and purchase intention.

Nowadays, with an extent of marketing mediums and online shopping experiences, customer engagement is a referred term in a brand's efforts in creating emotional ties which can influence word of mouth and upcoming sales (Dessart et al., 2015). A previous study by Barhemmati \& Ahmad (2015) found that social media marketing is significantly related to customer engagement. Social media may be used to engage with customers by creating value for them. Pütter (2017) also argued that social media, a platform that is used by the masses, support customer engagement. Following the arguments, a hypothesis is made accordingly as follows:

$\mathrm{H} 2$ : There is a positive relationship between social media marketing factors and customer engagement. 
Barhemmati and Ahmad (2015) mentioned in their research that the emotional ties between customers and brands that are made through engaging with the customers, offer the brands an immense prospect to achieve their marketing objectives that are related to customer relationship. These prospects may help the company in persuading customers to purchase the products or services offered. Based on the arguments, a hypothesis was made as follows:

H3: There is a positive relationship between customer engagement and purchase intention.

\section{Mediation}

The following section discusses the relationship among social media marketing, customer engagement and purchase intention. Husnain and Toor (2017) implied that if managed proficiently, the engagement created through social media marketing may lead to an extended relationship between the brand and the customer and will likely increase sales. Regarding the arguments, another hypothesis is made accordingly:

H4: Consumer engagement is a mediator of the relationship between social media marketing factors and purchase intention.

\section{Conceptual Framework}

Conceptual framework is illustrated in Figure 1 in accordance with the current research limitations. The independent variable consists of social media marketing components consisting of Entertainment, Interaction, Trendiness, Advertisement, Customization, Electronic Word-of-Mouth. The relationship between the independent and dependent variable is mediated by customer engagement. Meanwhile, the dependent variable of this study is Purchase Intention. The dimensions of Social Media Marketing variables of this research are taken from Kim and Ko (2012), Jo (2013), and Sano (2009). The Customer Engagement variables are taken from Vivek (2009), Bove et al. (2008), Bansal et al. (2004), Anderson (1998) and Mittal (1988). The Purchase Intention dimensions are taken from the studies of Husnain et al. (2017) and J. C. Wang \& Chang (2013).

Figure 1: Conceptual Framework

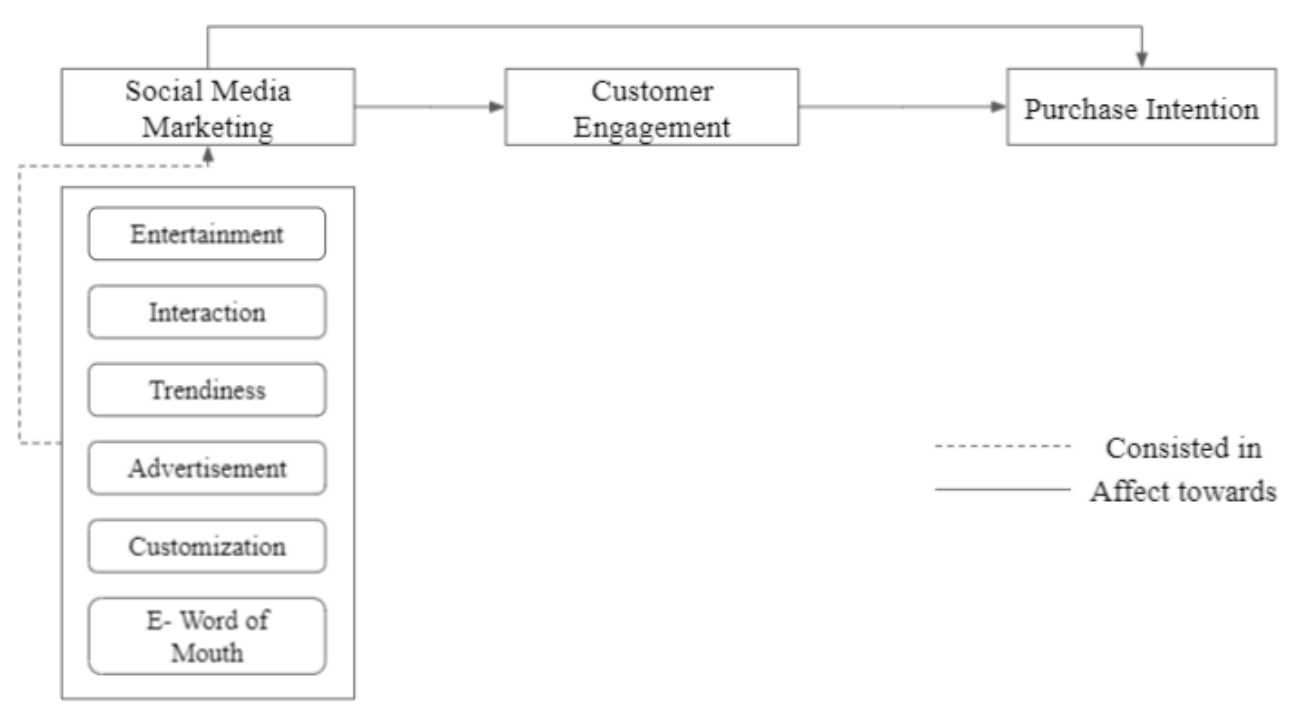




\section{Methodology}

\section{Population and Sampling}

Referring to Malhotra's Book of Marketing Research (2010), the researcher uses nonprobability sampling, specifically quota sampling for this research. Quota sampling is done by determining the control elements, which are; (1) Living in the areas of Jakarta, Tangerang, Bogor, Depok, or Bandung, (2) Either had bought products of, or seen the social media of any raw chicken brands. The population of this research are taken from areas with a growing number of probiotic chicken buyers and prospects to increase the validity of the data gathered. The control element or quota ensures that the composition of the sample is the same as the population accordingly. This sampling requires the respondents to follow the control elements, and that for a test-marketing study, the minimum size of the sample is 200 .

\section{Operationalization of Constructs}

The attributes and questions for the questionnaires are adapted respectively from previous literatures (Table 1). The questions regarding social media marketing in the questionnaire were adapted from previous research done by Jo (2013), Kim and Ko (2012) and Sano (2009). The questions regarding customer engagement are adapted from Vivek (2009), Bove et al. (2008), Bansal et al. (2004), Anderson (1998), and Mittal (1988). And the questions regarding purchase intention were adapted from Husnain et al. (2017) and Wang and Chang (2013). The questionnaire contains a series of questions that will assess the respondents' perception towards the topic. The questionnaire uses 5-Point Likert Scale, which consist of five points indicating; (1) Strongly disagree; (2) Disagree; (3) Neither agree nor disagree; (4) Agree; (5) Strongly agree.

Table 1: Constructs and References

\begin{tabular}{|c|c|c|c|}
\hline Variable & Dimension & Indicator & Reference \\
\hline \multirow{2}{*}{$\begin{array}{l}\text { Social } \\
\text { Media } \\
\text { Marketing }\end{array}$} & \multirow{2}{*}{$\begin{array}{l}\text { Entertainment } \\
(\text { ENT) }\end{array}$} & Using this brand's social media is fun & Jo (2013) \\
\hline & & $\begin{array}{l}\text { Content shown on this brand's social media } \\
\text { seems interesting }\end{array}$ & $\begin{array}{l}\text { Kim and Ko } \\
\text { (2012) }\end{array}$ \\
\hline
\end{tabular}

Interaction

(INT)

Trendiness (TRE)

Advertisement
(ADV)

Customization (CUS)

E-Word of Mouth (EWM)
This brand's social media enables information sharing with others

It is easy to have conversation or opinion exchange through this brand's social media

This brand's social media shows the newest information in their content

Using this brand's social media is trendy

I like the ads that this brand publishes on social media

Social media ads of this brand positively affect my perception towards this brand

The brand's social media provides the information that I need

I can easily get the information that I need from the directions on this brand's social media

I want to pass along information on this brand's social media to my friends

I would like to upload content from this
Jo (2013)

Kim and Ko

(2012)

Sano (2009)

Jo (2013)

Kim and Ko

(2012)

Sano (2009)

Jo (2013)

Jo (2013)

Kim and Ko

(2012)

Sano (2009)

Kim and Ko

(2012) 
brand's social media on my own social media

Customer

Engagement

(CEN)

Purchase

Intention

(PIN)
This brand has a lot of advantages resulting from it

This brand is relevant to my needs

This brand is very gratifying

I feel I have a bond with this brand

Vivek (2009)

I am motivated to respond to communications from this brand

This company goes out of its way for customers

This company always tries to do the right things for customers

This company has a genuine concern for customers

I feel emotionally attached to this company

I feel a sense of belonging with this brand

I mention about this brand to others

When I tell others about this brand, I tend to talk about it in detail

This brand is important to me

This brand means a lot to me

This brand matters to me

This brand is significant

This brand is of concern to me

It is likely that I will buy the products recommended by this brand

I will purchase this brand's products the next time I need probiotic chicken

Vivek (2009)

\author{
Vivek (2009)
}

Bove et al.

(2008)

Bansal et al. (2004)

Anderson

(1998)

Mittal (1988)

Husnain et al. (2017), Wang and Chang

(2013)

If a friend asked me for advice on which probiotic chicken products to buy, I

would advise them to buy this brand's products

I will definitely buy the products recommended by this brand

I have strong intentions to purchase the products recommended by this brand

Using social media of brands help me make better decisions before purchasing products

Using social media of brands help in increasing my interest in buying products

I am highly likely to buy products or services recommended by my friends on social media

\section{Participant Demographics}

Out of 219 responses collected, 215 is eligible to process, resulting in $98.17 \%$ eligibility rate. As seen in Table 2, most of the respondents are between the age of 18 and 25 (76.28 per cent). The distribution of males (47.4 per cent) and females (50.7 per cent) are almost equal. Of the 215 respondents, 20.93 
DOI: https://doi.org/10.47405/mjssh.v6i8.943

per cent were employed, 66.5 per cent are students, 14 per cent own businesses and 6 per cent are stay at home wives or husbands.

Table 2: Respondent Demographics

\begin{tabular}{|c|c|c|c|}
\hline Variables & Categories & Frequency & Percent \\
\hline \multirow[t]{4}{*}{ Age } & $18-25$ & 164 & 76.28 \\
\hline & $26-35$ & 20 & 9.30 \\
\hline & $36-45$ & 15 & 6.98 \\
\hline & $46-55$ & 16 & 7.44 \\
\hline \multirow[t]{3}{*}{ Gender } & Male & 102 & 47.44 \\
\hline & Female & 109 & 50.70 \\
\hline & Others & 4 & 1.86 \\
\hline \multirow[t]{4}{*}{ Occupation } & College Student & 143 & 66.51 \\
\hline & Employee or Freelancer & 45 & 20.93 \\
\hline & $\begin{array}{l}\text { Business Owner or } \\
\text { Entrepreneur }\end{array}$ & 14 & 6.51 \\
\hline & Housewife or Househusband & 13 & 6.05 \\
\hline \multirow[t]{3}{*}{ Living Partners } & Alone & 20 & 9.30 \\
\hline & With Friends & 8 & 3.72 \\
\hline & With Family & 187 & 86.98 \\
\hline \multirow[t]{4}{*}{ Household Size } & $1-2$ & 23 & 10.70 \\
\hline & $3-5$ & 142 & 66.05 \\
\hline & $6-7$ & 43 & 20.00 \\
\hline & above 7 & 7 & 3.26 \\
\hline
\end{tabular}

In terms of occupation, 86.98 per cent are reported to live with their families, 9.3 per cent live alone and 3.72 per cent live with their friends. Most of the respondents have three to five people in their household (66 per cent).

\section{Result}

\section{Measurement Model}

To ensure that the constructs used are valid and reliable, a convergent validity test, discriminant validity test, composite reliability test and indicator reliability test were conducted. The model uses constructs that are valid and reliable. Thus, all the constructs that do not pass the requirement are removed from the model. Table 3 shows the constructs that are valid and reliable, and further used in the model. All the constructs have Average Variance Extracted (AVE) values above 0.5 (Wong, 2013), making all of the constructs valid. The composite reliability also show values over 0.7 (Wong, 2013), ensuring that all of the constructs are reliable. 
DOI: https://doi.org/10.47405/mjssh.v6i8.943

Table 3: Results of the Convergent Validity and Composite Reliability Tests

\begin{tabular}{ccc}
\hline Variables & $\begin{array}{c}\text { Average Variance Extracted } \\
\text { (AVE) }\end{array}$ & Composite Reliability \\
\hline Entertainment & 0.685 & 0.812 \\
Interaction & 0.811 & 0.896 \\
Trendiness & 0.751 & 0.858 \\
Advertisement & 0.848 & 0.918 \\
Customization & 0.848 & 0.918 \\
E - Word of Mouth & 0.853 & 0.921 \\
Customer Engagement & 0.718 & 0.927 \\
Purchase Intention & 0.590 & 0.896
\end{tabular}

The indicators are also deemed valid according to the discriminant validity result. Table 4 shows that AVE values surpassing the values of each of the constructs' correlations (Wong, 2013), the constructs in this model have passed the convergent and discriminant validity requirements.

Table 4: Results of the Discriminant Validity Test

\begin{tabular}{crrrrrrrr}
\hline & \multicolumn{1}{c}{ ADV } & \multicolumn{1}{c}{ CEN } & CUS & EWM & ENT & INT & PIN & TRE \\
\hline ADV & $\mathbf{0 . 9 2 1}$ & & & & & & & \\
CEN & 0.586 & $\mathbf{0 . 8 4 7}$ & & & & & & \\
CUS & 0.691 & 0.607 & $\mathbf{0 . 9 2 1}$ & & & & & \\
EWM & 0.517 & 0.727 & 0.627 & $\mathbf{0 . 9 2 3}$ & & & & \\
ENT & 0.621 & 0.61 & 0.562 & 0.538 & $\mathbf{0 . 8 2 7}$ & & & \\
INT & 0.536 & 0.618 & 0.59 & 0.56 & 0.605 & $\mathbf{0 . 9 0 1}$ & & \\
PIN & 0.534 & 0.695 & 0.571 & 0.622 & 0.557 & 0.534 & $\mathbf{0 . 7 6 8}$ & \\
TRE & 0.65 & 0.667 & 0.641 & 0.585 & 0.581 & 0.632 & 0.512 & $\mathbf{0 . 8 6 7}$ \\
\hline
\end{tabular}

The outer loadings value of the indicators used in the model have all surpassed 0.7 (Wong, 2013). It can be concluded that all the indicators are reliable according to the indicator reliability results.

Table 5: Results of the Indicator Reliability Test

\begin{tabular}{cccc}
\hline Variable & Indicators & Outer Loadings & Indicator Reliability \\
\hline \multirow{3}{*}{ Entertainment } & ENT1 & 0.899 & Reliable \\
& ENT2 & 0.749 & Reliable \\
\multirow{2}{*}{ Interaction } & INT1 & 0.899 & Reliable \\
& INT2 & 0.902 & Reliable \\
\multirow{2}{*}{ Trendiness } & TRE1 & 0.824 & Reliable \\
& TRE2 & 0.907 & Reliable \\
Advertisement & ADV1 & 0.915 & Reliable \\
& ADV2 & 0.927 & Reliable \\
Customization & CUS1 & 0.927 & Reliable \\
\hline
\end{tabular}



DOI: https://doi.org/10.47405/mjssh.v6i8.943

\begin{tabular}{cccl}
\hline \multirow{3}{*}{ E - Word of Mouth } & EWM1 & 0.928 & Reliable \\
& EWM2 & 0.919 & Reliable \\
& CEN1 & 0.790 & Reliable \\
& CEN2 & 0.873 & Reliable \\
& CEN3 & 0.849 & Reliable \\
Customer Engagement & CEN4 & 0.859 & Reliable \\
& CEN5 & 0.864 & Reliable \\
& PIN1 & 0.817 & Reliable \\
& PIN2 & 0.781 & Reliable \\
& PIN3 & 0.711 & Reliable \\
& PIN4 & 0.737 & Reliable \\
& PIN5 & 0.750 & Reliable \\
& PIN6 & 0.808 & Reliable \\
\hline \multirow{3}{*}{ Purchase Intention } & & & \\
\hline
\end{tabular}

The data used are also required to be free of collinearity. According to Table 6 , the indicators used in the model have VIF values below 5 (Wong, 2013), making them free of collinearity problems.

Table 6: Results of the Collinearity Test

\begin{tabular}{cccccc}
\hline Variable & Indicators & VIF & Variable & Indicators & VIF \\
\hline \multirow{2}{*}{ Entertainment } & ENT1 & 1.172 & Customer & CEN1 & 1.911 \\
& ENT2 & 1.172 & Engagement & CEN2 & 3.052 \\
Interaction & INT1 & 1.632 & & CEN3 & 2.411 \\
& INT2 & 1.632 & & CEN4 & 3.003 \\
Trendiness & TRE2 & 1.35 & & CEN5 & 2.751 \\
& TRE1 & 1.35 & Purchase & PIN1 & 3.147 \\
Advertisement & ADV1 & 1.937 & Intention & PIN2 & 2.981 \\
& ADV2 & 1.937 & & PIN3 & 2.435 \\
Customization & CUS1 & 1.937 & & PIN4 & 2.765 \\
& CUS2 & 1.937 & & PIN5 & 1.834 \\
& EWM1 & 1.992 & & PIN6 & 2.203 \\
E - Word of Mouth & EWM2 & 1.992 & & & \\
& & & & &
\end{tabular}

\section{Structural Model and Hypotheses Testing}

The examination of the hypotheses is done by analysing the T-values based on $95 \%$ confidence interval (Setiaman, 2020). The relationships shown in Table 7 show T-values of over 1.96, meaning that they are significantly positively correlated. The model's coefficient of determination $\mathrm{R}^{2}$ values surpassed the value 0.33 but are below 0.67 , meaning that the constructs have moderate strength to explain the variances in the corresponding constructs. The remaining percentage of variances of the constructs are explainable by the constructs that are not used in this research. The results imply that entertainment can influence $13.6 \%$ of customer engagement and $12 \%$ of purchase intention significantly. Therefore, H1 and $\mathrm{H} 2$ are supported for the entertainment factor. Thus, entertainment's power to influence customer engagement is higher than its' power towards purchase intention. Similarly, e - word of mouth can influence $41.6 \%$ of customer engagement and $16.5 \%$ of purchase intention significantly. Therefore, H1 and $\mathrm{H} 2$ are supported for the $\mathrm{e}$ - word of mouth factor. Meanwhile, trendiness can influence $21.1 \%$ of customer engagement, and does not influence purchase intention directly. Therefore, H1 is supported for the trendiness factor. Additionally, customer engagement can significantly positively influence $40.4 \%$ of purchase intention. Hence, $\mathrm{H} 3$ is supported. 
Table 7: Structural Model Analysis

\begin{tabular}{ccccc}
\hline Relationships & $\begin{array}{c}\text { Path } \\
\text { Coefficients }\end{array}$ & $\begin{array}{c}\text { T Statistics } \\
(\mid \mathbf{O} \text { (SDEV|) }\end{array}$ & $\begin{array}{c}\text { (Coefficient of } \\
\text { Determination) } \\
\mathbf{R}^{\mathbf{2}}\end{array}$ & Hypothesis \\
\hline $\begin{array}{c}\text { Entertainment } \rightarrow \text { Customer } \\
\quad \text { Engagement }\end{array}$ & 0.136 & 1.975 & 0.653 & H1 Accepted \\
$\begin{array}{c}\text { Entertainment } \rightarrow \text { Purchase } \\
\quad \text { Intention }\end{array}$ & 0.12 & 2.001 & 0.549 & H2 Accepted \\
$\quad \begin{array}{c}\text { Trendiness } \rightarrow \text { Customer } \\
\text { Engagement }\end{array}$ & 0.211 & 2.716 & 0.653 & H1 Accepted \\
$\begin{array}{c}\text { E-Word of Mouth } \rightarrow \text { Customer } \\
\quad \text { Engagement }\end{array}$ & 0.416 & 6.987 & 0.653 & H1 Accepted \\
$\begin{array}{c}\text { E-Word of Mouth } \rightarrow \text { Purchase } \\
\text { Intention }\end{array}$ & 0.165 & 4.62 & 0.549 & H2 Accepted \\
$\quad \begin{array}{c}\text { Customer Engagement } \rightarrow \\
\text { Purchase Intention }\end{array}$ & 0.404 & 4.201 & 0.549 & H3 Accepted \\
\hline$\quad$
\end{tabular}

\section{Mediation}

In addition to analysing the direct effect, this research also tested the mediating role of customer engagement on the relationship between social media marketing and purchase intention using Baron and Kenny's (1986) approach. As shown in Table 7, the factors entertainment and e - word of mouth are significantly related to the customers' purchase intention. This fulfils the first requirement that the independent and dependent variables' relationship must be significant. Additionally, both factors alongside trendiness also have a significant relationship with customer engagement. Thus, entertainment and $\mathrm{e}$ - word of mouth fulfil the second requirement that the relationship between the independent variable and the mediator must be significant. It is known that the presence of customer engagement in the model reduces the effect of entertainment and $\mathrm{e}$ - word of mouth towards purchase intention. Therefore, the last requirement is fulfilled and $\mathrm{H} 4$ is supported for the relationship between entertainment and $\mathrm{e}$ - word of mouth towards purchase intention.

Figure 3: Mediating Effect

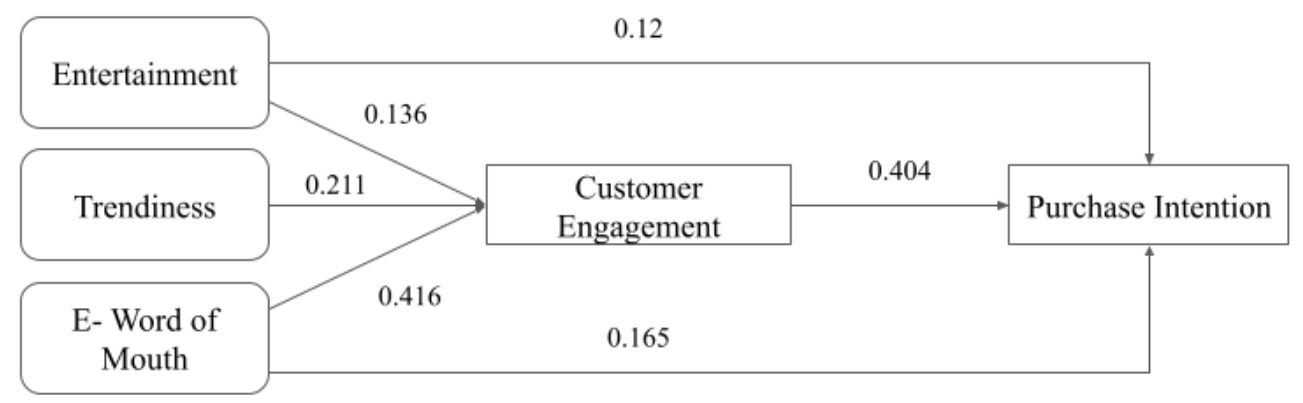

\section{Discussion}

The findings of the analysis show the relationship of social media marketing, customer engagement, and purchase intention. Previous literatures have identified that social media marketing and customer engagement are inseparable due to social media's interactive nature (Barger, Peltier, and Schultz, 2016), as the use of social media itself supports customer engagement (Pütter, 2017). Cummins et al. (2014) also mentioned that the role of customer engagement in social media could possibly increase profitability. The literatures are in line with the finding of this research that finds a significantly positive influence from social media marketing to customer 
engagement, and lower power to no significantly positive direct influence of social media marketing to purchase intention. Hence, the presence of customer engagement in this study accommodates the reason for companies to implement social media marketing to increase the customers' purchase intention.

Data analysis show that the Entertainment and E - Word of Mouth aspects appear to have a significant indirect influence towards the customers' purchase intention in the case of probiotic chicken industry in Indonesia. As predicted, customer engagement mediates the relationship between the aspects and purchase intention. Thus, probiotic chicken brands need to maximize these aspects of social media marketing, to enhance the brand-customer engagement and potentially leverage the customers' intention to purchase. While the relevance of the contents of the brands' social media appears to have a significant influence on the customer engagement. Hence, the brands can also consider maximizing the trendiness of its' social media contents to drive higher brand-customer engagement.

\section{Conclusion}

The purpose of this research is to explore the social media marketing aspects that influence the customers' intention to purchase probiotic chicken products. The researcher has analyzed the social media marketing aspects that includes entertainment, interaction, trendiness, advertisement, customization, and e - word of mouth. During the analysis, the researcher also found that customer engagement mediates the relationship between social media marketing and purchase intention. The data was collected using a Google Form questionnaire that was distributed to 215 respondents in Jakarta, Bogor, Depok, Tangerang, Bekasi, and Bandung city that have been a customer of or have seen the social media accounts that sell raw chicken. The data was analyzed using Partial Least Squares - Structural Equation Modelling.

The findings of this research may contribute to the world of business research in many ways. The study found that the aspect of trendiness is revealed to have a direct influence towards customer engagement. Thus, increasing the quality of the aspect potentially increases the customer engagement. While the aspects of entertainment and e - word of mouth have both a direct and indirect influence on purchase intention and increasing the quality of the aspects may both potentially increase brand-customer engagement and purchase intention. Nonetheless, this study hghlights the ability of social media's outcome to impact customers' purchase intention. The study also highlighted that the relationship between the brand and the customer delivers the values of entertainment and $\mathrm{e}$ - word of mouth of social media marketing to potentially increase the customers' intention to purchase. The emotional tie created with the customers may amplify the effect of the entertaining and shareable content to leverage the customers' intentions to buy probiotic chicken products.

The results founded in this study imply that probiotic chicken sellers that market their products through social media need to maximize their accounts' entertainment values. Because through giving the customers feelings of joy while observing their social media accounts, can both give the customers a feel of an emotional tie with the brand and could also directly increase the customers' intention to purchase. As of trendiness values, the information that is displayed on the brands' social media account need to be up-to-date and show information that are relevant to the current conditions of the society. Showing that the brand keeps up with the trend gives a passageway for the customers to feel closer or more related with the brand. This will increase the brand-customer relationship. Meanwhile, increasing electronic word of mouth values of the brands' social media accounts may lead to a stronger brandcustomer relationship and the purchase intention directly. The contents of the social media account has to be shareable, which means that customers can freely and willingly share it to their friends and families. With the high shareability of the social media contents, the brand-customer relationship will be built as the customers' intention to buy the probiotic chicken also rises.

This research is limited to customers of social media raw chicken brands in the cities of Jakarta, Bogor, Depok, Tangerang, Bekasi, and Bandung. Therefore this study can be developed through analyzing 
samples from other cities. The research also only implies within the probiotic chicken sector, while other sectors in the poultry industry remain unexplored. Previously, it has been revealed that the coefficient of determination of each of the relationships is moderate, and less than half of the variances of the dependent variables remain unexplained. Hence, further research can be conducted to find out the corresponding variables that are not yet explained in this research.

\section{References}

Afrilian, D. (2020, December 15). 8 Prediksi Tren Makanan Sehat Tahun 2021 Menurut Ahli Gizi. DetikFood. https://food.detik.com/info-sehat/d-5294832/8-prediksi-tren-makanan-sehat-tahun2021-menurut-ahli-gizi

Anderson, E. W. (1998). Customer Satisfaction and Word of Mouth. Journal of Service Research, 1(1), 5-17. https://doi.org/10.1177/109467059800100102

Badan Pusat Statistik. (n.d.). Retrieved April 17, 2021, from https://www.bps.go.id/

Bansal, S., H., Irving, P. G. \& Taylor, S. F. (2004). A Three-Component Model of Customer Commitment to Service Providers. Journal of the Academy of Marketing Science, 32(3), 50234.

Barger, V. A., Peltier, J. W. \& Schultz, D. E. (2016). Social media and consumer engagement: A review and research agenda. Journal of Research in Interactive Marketing, 10(4), 268-287.

Barhemmati, N. \& Ahmad, A. (2015). Effects of social network marketing (SNM) on consumer purchase behavior through customer engagement. Journal of Advanced Management Science, 3(4), 307-311.

Baron, R. M. \& Kenny, D. . (1986). The moderator-mediator variable distinction in social psychological research: Conceptual, strategic, and statistical considerations. Journal of Personality and Social Psychology, 51(6), 1173-1182.

Bove, Liliana, L., Simon, J., Pervan, Beatty, S. E. \& Shiu, E. (2008). Service Worker Role in Encouraging Customer Organizational Citizenship Behaviors. Journal of Business Research.

Bowden, J. (2009). The Process of Customer Engagement: A Conceptual Framework. Journal of Marketing Theory and Practice, 17(1), 63-74.

Bruhn, M., Schoenmueller, V. \& Schäfer, D. B. (2012). Are social media replacing traditional media in terms of brand equity creation? Management Research Review, 35(9), 770-790. https://doi.org/10.1108/01409171211255948

Chang, M. K., Cheung, W. \& Lai, V. S. (2005). Literature derived reference models for the adoption of online shopping. Information \& Management, 42(4), 543-559.

Chen, J. (2021). 36 Social Media Marketing Statistics to Know for 2021 | Sprout Social. Sprout Social. https://sproutsocial.com/insights/social-media-statistics/

Cummings, M. (2007). Consumer engagement perspectives: a tool for ensuring advertising's impact? https://pdfs.semanticscholar.org/

Cummins, S., Peltier, J. W., Schibrowsky, J. A. \& Nill, A. (2014). Consumer behavior in the online context. Journal of Research in Interactive Marketing, 8, 169-202.

Deigado, M. (2018, January 31). Small Business Websites in 2018 | Clutch.co. Clutch Report. https://clutch.co/website-builders/resources/small-business-websites-2018

Dessart, L., Veloutsou, C. \& Morgan-Thomas, A. (2015). Consumer engagement in online brand communities: A social media perspective. Journal of Product and Brand Management, 24(1), 28-42. https://doi.org/10.1108/JPBM-06-2014-0635

Diallo, M. F. (2012). Effects of store image and store brand price image on store brand purchase intention. Journal of Retailing and Consumer Services, 19(3), 360-367.

Dodds, W., Monroe, K. \& Grewal, D. (1991). Effects of price, brand, and store information on buyers' product evaluation. Journal of Marketing Research, 28(3), 307-319. https://doi.org/10.2307/3172866

Guo, L. (2016). How Instagram Make Commercials More Targeted ®. Drexel University.

Hazlett, K. (2010). Marketing to the Social Web: How Digital Customer Communities Build Your Business (2nd ed.). Journal of Consumer Marketing, 27(3), 293-295. https://doi.org/10.1108/07363761011038383

Husnain, M., Toor, A. \& Hussain, T. (2017). The impact of social network marketing on consumer 
purchase intention in Pakistan: Consumer engagement as a mediator. Asian Journal of Business and Accounting, 10, 167-199.

Hutter, K., Hautz, J., Dennhardt, S. \& Füller, J. (2013). The impact of user interactions in social media on brand awareness and purchase intention: the case of MINI on Facebook. Journal of Product \& Brand Management, 22(5-6), 342-351.

Jo, S. A. (2013). Impact of Company's SNS Marketing Activities on Perceived Value and Customer's Loyalty: Focusing on Facebook [Hong-IK University]. In International Journal of Data and Network Science (Vol. 4). https://doi.org/10.5267/j.ijdns.2020.3.002

Kantar Worldpanel Indonesia. (2020). FMCG Monitor - Full Year 2020 - Indonesian - Kantar Worldpanel. https://www.kantarworldpanel.com/id/News/FMCG-Monitor-Full-Year-2020

Kaplan, A. M. (2015). Social Media, the Digital Revolution, and the Business of Media. International Journal on Media Management, 17(4), 197-199. https://doi.org/10.1080/14241277.2015.1120014

Kaplan, A. M. \& Haenlein, M. (2010). Users of the world, unite! The challenges and opportunities of Social Media. Business Horizons, 53(1), 59-68. https://doi.org/10.1016/j.bushor.2009.09.003

Kim, A. J. \& Ko, E. (2012). Do social media marketing activities enhance customer equity? An empirical study of luxury fashion brand. Journal of Business Research, 65(10). https://doi.org/10.5267/j.ijdns.2020.3.002

Krumm, J., Davies, N. \& Narayanaswami, C. (2008). User-generated content. In IEEE Pervasive Computing (Vol. 7, Issue 4, pp. 10-11). https://doi.org/10.1109/MPRV.2008.85

Malhotra, N. K. (2010). MARKETING RESEARCH: AN APPLIED ORIENTATION (6th ed.). Pearson Education.

Mittal, B. (1988). The Role of Affective Choice Mode in the Consumer Purchase of Expressive Products. Journal of Economic Psychology, 9, 499-524.

Pütter, M. (2017). The Impact of Social Media on Consumer Buying Intentions. Journal of Marketing, 3(1), 7-13.

Rose, S., Clark, M., Samouel, P. \& Hair, N. (2012). Online customer experience in e-retailing: An empirical model of antecedents and outcomes. Journal of Retailing, 88(2), 308-322.

Sano, K. (2009). Do social media marketing activities enhance customer satisfaction, promote positive WOM and affect behavior intention. Doshisha Commerce Journal, 3-4(66), 491-515.

Setiaman, S. (2020). Tutorial Analisis Partial Least Square Dengan Smart-PLS (3rd ed.).

Setyowati, D. (2019). Instagram Klaim 70\% Pengguna Akun Bisnisnya Serap Tenaga Kerja Katadata.co.id.

KataData. https://katadata.co.id/desysetyowati/digital/5e9a55215fcd7/instagram-klaim-70-pengguna-akunbisnisnya-serap-tenaga-kerja

Sheth, Bruce, I. N. \& Gross, B. L. (1991). Why We Buy What We Buy: A Theory of Consumption Values. Journal of Business Research, 22, 70-159.

Stephanie, C. (2021, February 23). Berapa Lama Orang Indonesia Akses Internet dan Medsos Setiap Hari? Halaman all - Kompas.com. Kompas.Com. https://tekno.kompas.com/read/2021/02/23/11320087/berapa-lama-orang-indonesia-aksesinternet-dan-medsos-setiap-hari-?page=all

Thamizhvanan, A. \& Xavier, M. J. (2013). Determinants of customers' online purchase intention: an empirical study in India. Journal of Indian Business Research, 5(1), 17-32.

Trifiana, A. (2019). Ayam Organik dan Ayam Probiotik, Mana yang Lebih Sehat? https://www.sehatq.com/artikel/ayam-probiotik-dan-ayam-organik-lebih-mahal-tapi-lebih-sehat

Vivek, S. D. (2009). A scale of Consumer Engagement. https://www.researchgate.net/publication/228798775_A_scale_of_Consumer_Engagement

Wang, J.-C. \& Chang, C.-H. (2013). How online social ties and product-related risks influence purchase intentions: A Facebook experiment. Electronic Commerce Research and Applications, 12(5), 337-346. https://doi.org/10.1016/j.elerap.2013.03.003

Wang, J. C. \& Chang, C. H. (2013). How online social ties and product-related risks influence purchase intentions: A Facebook experiment. Electronic Commerce Research and Applications, 12(5), 337-346. https://doi.org/10.1016/j.elerap.2013.03.003

Wang, Z., Zhang, M., Sun, H. \& Zhu, G. (2016). Effects of standardization and innovation on mass customization: An empirical investigation. Technovation, 48-49, 79-86. https://doi.org/10.1016/j.technovation.2016.01.003 
DOI: https://doi.org/10.47405/mjssh.v6i8.943

Wong, K. K.-K. (2013). Partial least square structural equation modeling (PLS-SEM) techniques using SmartPLS. Marketing Bulletin, $\quad$ 24, 1-32. https://www.researchgate.net/publication/268449353_Partial_least_square_structural_equation_ modeling_PLS-SEM_techniques_using_SmartPLS 